\section{Economic Return in Production of Lettuce and Cantaloupe Is Affected by Cropping System and Management Practice}

\author{
Edmund J. Ogbuchiekwe and Milton E. McGiffen, Jr. ${ }^{1}$ \\ Department of Botany and Plant Sciences, University of California, Riverside, \\ CA 92521-0124
}

\author{
Mathieu Ngouajio \\ Department of Horticulture, Michigan State University, East Lansing, MI \\ 48824-1325
}

Additional index words. cost-benefit analysis, cover crops, organic production, sustainable agriculture, vegetables

\begin{abstract}
Economic analysis compared the returns of cropping systems and management practices for production of fall lettuce (Lactuca sativa $\mathrm{L}$.) and spring cantaloupe ( $\mathrm{Cucu}$ mis melo) following summer cover crops. The cover crop treatments included: cowpea [Vigna unguiculata (L.) Walp.] incorporated into the soil in the fall, cowpea used as mulch in the fall, sorghum sudangrass [Sorghum bicolor $(\mathrm{L}$.$) Moench] incorporated into the$ soil in the fall, and a bare ground control. Lettuce and cantaloupe were managed using conventional, integrated, and organic practices. The effect of each cropping system and management practice on crop yield, cost of production and net return was determined. In 1999 and 2000, yield and net return were greatest for cantaloupe and lettuce when the cowpea cover crop was incorporated into the soil before planting. The effect of crop management practice varied with type of cover crop. When lettuce was planted into cowpea-incorporated treatment in 1999, conventional management had the highest cash return followed by integrated crop management. In 2000, organically-grown lettuce after cowpea incorporated had the highest net return followed by integrated crop management grown under cowpea incorporated treatments. In 1999 and 2000, integrated cantaloupe following cowpea-incorporated treatment had the highest yield and cash-return. A $20 \%$ price premium for organic produce increased the net returns for the organic-grown lettuce and cantaloupe. Organic lettuce following cowpea-incorporated treatments produced a high net of $\$ 2,516 / \mathrm{ha}$ in 1999 and $\$ 5,971 / \mathrm{ha}$ in 2000 . The net returns due to $20 \%$ organic premium price varied between 1999 and 2000 in cantaloupe production. They were highest for organic cantaloupe after bareground with a net return of \$4,395 in 1999 and $\$ 3,148$ in $\mathbf{2 0 0 0}$ for organic cantaloupe after sudangrass.
\end{abstract}

Lettuce and cantaloupe are important components of the vegetable production systems in California. Lettuce is a cool-season crop that is planted in fall in the low desert for harvest in December. Cantaloupe is a warmseason vegetable generally planted in March for a June harvest. Weed, disease, and pest management often include methyl bromide fumigation under plastic mulch. However, due to the phase-out of methyl bromide, concerns about the effects of conventional production systems on the environment and health, and growing interests in organic produce, vegetable growers have embraced sustainable agricultural techniques (Batte et al., 1993; Bond et al., 1998; Buys, 1993; Clark et al., 1999; Liebman and Davis, 2000). In addition

Received for publication 10 June 2003. Accepted for publication 26 Nov. 2003. We thank Laura Tourte, Trent Teegerstrom, and Gene Miyao comments on the early version of this work. This research was partially supported by USDA's Western Region Sustainable Agriculture Research and Education program (WRSARE)

${ }^{1}$ To whom requests should be addressed; e-mail milt@ucr.edu. to sustainable agricultural practice, vegetable growers have integrated summer cover crops and the use of compost into their production system (Creamer and Baldwin, 2000; McGiffen et al., 2000; Ngouajio and McGiffen, 2001). Many growers have begun to plant a summer cover crop before fall planted lettuce. The summer cover crops commonly used in California are sudangrass (Sorghum bicolor) and cowpea (Vigna unguiculata). The cash crop is usually managed either conventionally with synthetic fertilizers or organically with compost amendments (Ngouajio and McGiffen, 2002). The integration of summer cover crop into vegetable production systems has resulted in increased yields in both lettuce and cantaloupe (Ngouajio, unpublished data). Our goal was to determine the economic viability of different cropping systems and management practices, using summer cover crops, fall-planted lettuce, and spring-planted cantaloupe as a model for sustainable farming systems.

\section{Materials and Methods}

Field experiments were established at the
University of California Desert Station in the Coachella Valley from 1998 to 2001 to study the effect of cover crops and management practices on vegetable production. The cropping sequence was summer cover crops followed by 'Shining Star' lettuce in the fall and 'Magellan' cantaloupe in the spring. Summer cover crops were sown in July of each year and included 'Iron Clay' cowpea or 'Piper' sudangrass. Lettuce and cantaloupe were transplanted at densities of 45,000 and 15,000 plants per hectare, respectively, with two rows per bed for lettuce and one row per bed for cantaloupe.

The experiment was a split-plot with a randomized complete block design and four replications. Main plot treatments were summer cowpea used as mulch in the fall, summer cowpea incorporated into the soil in the fall, summer sudangrass incorporated into the soil in the fall, and summer fallow (bare-ground). Each main plot treatment was subdivided into three crop management practices: i) conventional (standard management practice), where synthetic fertilizer $15 \mathrm{~N}-15 \mathrm{P}-15 \mathrm{~K}$ was applied at the rate of $170 \mathrm{~kg} \cdot \mathrm{ha}^{-1}$, ii) organic where compost (50\% chicken manure and 50\% yard waste) was applied and incorporated into the soil at $5 \mathrm{Mt} \cdot \mathrm{ha}^{-1}$, and iii) an integrated crop system (low-input system) where pesticide was only applied when insect populations reached economic threshold levels, however fertilizer used $(15 \mathrm{~N}-15 \mathrm{P}-15 \mathrm{~K})$ was the same as in conventional treatments. Main plot sizes were $12 \mathrm{~m}$ long $\times 9 \mathrm{~m}$ wide and consisted of six beds. Each main plot was subdivided into $4 \mathrm{~m}$ long $\times 3$ m wide to accommodate the three crop management practices. To allow year-to-year buildup of treatment effects, all treatments were maintained in the same location throughout the duration of the experiment.

To maintain consistency across all crops, sprinkler irrigation was used to establish the cash crop; then drip irrigation was used for the remainder of the season. Lettuce and cantaloupe were harvested at maturity. Lettuce was harvested on 13 Dec. 1999 and 15 Dec. 2000. Cantaloupe was harvested twice on 8 and 16 June 2000; and 4 and 15 June 2001. Yield was sorted into marketable and non-marketable yield. Yield data were also subjected to analysis of variance (ANOVA) for treatment and years, and LSD separated the treatment means at $P \leq 0.05$.

Marketable yield was used to perform the partial budget analysis (Ogbuchiekwe and McGiffen, 2001) that compares the effect of cover crop treatments and crop management programs on yield, gross value, net return, and total variable cost. Gross value is the market price per box of the crop multiplied by the number of boxes harvested. The gross values of lettuce and cantaloupe were based on the average price of $\$ 8.00 / \mathrm{box}(15.9 \mathrm{~kg})$ for lettuce and $\$ 7.70 / \mathrm{box}(18 \mathrm{~kg})$ for cantaloupe (USDA, 2001). To simplify our analysis and see the effect of yield variability within years and treatments, it was assumed that prices for fresh lettuce and cantaloupe were the same for 1999 and 2000. The net return for each treatment represented total gross values less 
total variable cost. Total variable costs consist of production and harvest costs. Production costs include adjusted standard desert conventional production cost, land rent and cash overhead. The production operation cost is the same in 1999 and 2000 for lettuce or cantaloupe (Table 3 and 5). Standard desert conventional production costs for leaf lettuce and cantaloupe (Mayberry et al., 1995) were adapted to reflect actual costs for the specific cover crops and crop management practices used in our experiment (e.g., labor for hoeing, fertilizer, compost and pesticide application costs). The harvest cost was adjusted to reflect the variation in crop yield for each treatment in each year. The sum total of variable costs was used to calculate the economic value of each cropping system and net return from harvesting lettuce and cantaloupe. The net return is not net profit, since net return estimates include total variable costs common to all treatments that are specific for our study (Ogbuchiekwe and McGiffen, 2001).

A sensitivity analysis was performed using organic premium prices. Sensitivity analysis identified the parameters, which, if varied slightly, changed net returns and costs (Centro Internacional de Mejoramiento de Maiz y Trigo, 1988b). Commodities that are produced organically can often be sold for a premium price of $20 \%$ more than conventionally grown produce (Brumfield et al., 1999). Therefore, the values of organically grown lettuce and cantaloupe were re-calculated using the $20 \%$ premium price since there was no published price recorded for organic grown lettuce or cantaloupe. This corresponded to $\$ 9.60$ and $\$ 9.24$ per box for cantaloupe and lettuce, respectively.

\section{Results and Discussions}

Effect of cover crop on net return. Lettuce net return in 1999 was greatest following incorporated cowpea cover crop (1,226 boxes/ha), with a net return of $\$ 2,732 / \mathrm{ha}$. The next best treatment was lettuce grown on no cover crop (bareground) with 990 boxes/ha and a net return of $\$ 2,291 /$ ha. The system with cowpea mulch produced 948 boxes/ha and returned $\$ 1,662 / \mathrm{ha}$. Lettuce grown after a sudangrass cover crop lost $\$ 162$ from 552 boxes/ha.

Cowpea-incorporated treatments had the highest yield, with 1,466 boxes/ha harvested in 2000 for a net return of $\$ 3,656 /$ ha (Table 1). Lettuce following cowpea mulch returned $\$ 2,389$ with 1137 boxes/ha. Lettuce yields in 2000 were greater than in 1999 for most treatments, and lettuce grown after sudangrass had a positive return of $\$ 2,414$ on 1,137 boxes/ha. Lettuce grown in bareground returned only $\$ 1,610 /$ ha due to low yield ( 813 boxes/ha) in 2000 .

Cantaloupe grown after cowpea-incorporated treatments had the highest net return in 1999 with $\$ 2,400 /$ ha from 1,186/ha (Table 2). Cantaloupe after sudangrass returned $\$ 2,126$ with 1,112 boxes/ha compared to $\$ 1,988$ for cantaloupe grown in the fallow treatments. Cantaloupe grown in cowpea mulch had the lowest net return, with 691 boxes/ha and \$594/ha.
In general, cantaloupe yield in 2000 was much higher than 1999, which accounted for the higher returns obtained in the 2000 . Cantaloupe grown after cowpea-incorporated treatments maintained the highest net return of $\$ 4,354 /$ ha with 1,714 boxes/ha. The net return on cantaloupe after sudangrass was also higher returning $\$ 3,296 /$ ha with 1,428 boxes/ha. Cantaloupe after bareground or cowpea mulch returned $\$ 3,105 /$ ha and $\$ 1,175 /$ ha from 1,250 and 848 boxes per ha in 2000 .

Combined effect of cover crop and management practice on net return. The next analysis focuses on economic returns from the three management systems (conventional, integrated, and organic) under each cover crop system. Lettuce and cantaloupe yield data were used to calculate gross return, total variable cost and net return. Net returns from the different management practices varied greatly with year and the cover crop system.

Lettuce. In 1999, the organic system produced the lowest net return, irrespective of the prior cover crop system (Table 4). Organic lettuce production following sudangrass resulted in a net loss of $\$ 1,983 / \mathrm{ha}$. Within individual cover crop system, net returns were greatest

Table 1. Net return from cropping system in production of fall leaf lettuce in 1999 and 2000 based upon a partial budget analysis all calculated value in (\$/ha).

\begin{tabular}{|c|c|c|c|c|c|c|}
\hline Treatment & $\begin{array}{c}\text { Avg } \\
\text { yield } \\
\text { (boxes/ha) }\end{array}$ & $\begin{array}{l}\text { Gross } \\
\text { return }^{2}\end{array}$ & $\begin{array}{c}\text { Total } \\
\text { production } \\
\text { cost }^{y}\end{array}$ & $\begin{array}{c}\text { Harvest } \\
\operatorname{cost}^{\mathrm{x}}\end{array}$ & $\begin{array}{c}\text { Total } \\
\text { variable } \\
\text { cost }^{\mathrm{w}}\end{array}$ & $\begin{array}{l}\text { Net } \\
\text { return }\end{array}$ \\
\hline \multicolumn{7}{|l|}{1999} \\
\hline Cowpea incorporated & 1226 & 9808 & 1988 & 5088 & 7076 & 2732 \\
\hline Cowpea mulch & 948 & 7584 & 1988 & 3934 & 5922 & 1662 \\
\hline Bare-ground & 990 & 7920 & 1520 & 4109 & 5629 & 2291 \\
\hline Sudan-grass & 552 & 4416 & 1963 & 2291 & 4254 & -162 \\
\hline $\operatorname{LSD}_{(0.05)}$ & 112 & --- & --- & --- & --- & --- \\
\hline \multicolumn{7}{|l|}{2000} \\
\hline Cowpea incorporated & 1466 & 11728 & 1988 & 6084 & 8072 & 3656 \\
\hline Cowpea mulch & 1137 & 9096 & 1988 & 4719 & 6707 & 2389 \\
\hline Bare-ground & 813 & 6504 & 1520 & 3374 & 4894 & 1610 \\
\hline Sudan-grass & 1137 & 9096 & 1963 & 4719 & 6682 & 2414 \\
\hline $\operatorname{LSD}_{(0.05)}$ & 153 & --- & --- & --- & --- & --- \\
\hline
\end{tabular}

${ }^{2}$ Gross return was calculated as average price of $\$ 8.00 /$ box multiply by average boxes /ha.

y Total production cost includes all cost for growing cover crop excluding cost of harvesting lettuce.

${ }^{x}$ Harvest was adjusted based on number of boxes harvested per treatment multiply by $\$ 4.15$ picking cost. wTotal variable cost include production and harvest cost.

"Net return was calculated as gross return minus total variable cost.

Table 2. Net return from cropping system in production of spring cantaloupe in 1999 and 2000 based upon a partial budget analysis all calculated value in $(\$ / \mathrm{ha})$.

\begin{tabular}{|c|c|c|c|c|c|c|}
\hline Treatment & $\begin{array}{c}\text { Avg } \\
\text { yield } \\
\text { (boxes/ha) }\end{array}$ & $\begin{array}{l}\text { Gross } \\
\text { return }\end{array}$ & $\begin{array}{c}\text { Total } \\
\text { production } \\
\text { cost }^{y}\end{array}$ & $\begin{array}{c}\text { Harvest } \\
\cos ^{\mathrm{x}}\end{array}$ & $\begin{array}{c}\text { Total } \\
\text { variable } \\
\text { cost }^{w}\end{array}$ & $\begin{array}{c}\text { Net } \\
\text { return }\end{array}$ \\
\hline \multicolumn{7}{|l|}{1999} \\
\hline Cowpea incorporated & 1186 & 9132 & 1988 & 4744 & 6732 & 2400 \\
\hline Sudan-grass & 1112 & 8562 & 1988 & 4448 & 6436 & 2126 \\
\hline Bare-ground & 948 & 7300 & 1520 & 3792 & 5312 & 1988 \\
\hline Cowpea mulch & 691 & 5321 & 1963 & 2764 & 4727 & 594 \\
\hline $\operatorname{LSD}_{(0.05)}$ & 377 & --- & & & & \\
\hline \multicolumn{7}{|l|}{$2000_{(0.05)}$} \\
\hline Cowpea incorporated & 1714 & 13198 & 1988 & 6856 & 8844 & 4354 \\
\hline Sudan-grass & 1428 & 10996 & 1988 & 5712 & 7700 & 3296 \\
\hline Bare-ground & 1250 & 9625 & 1520 & 5000 & 6820 & 3105 \\
\hline Cowpea mulch & 848 & 6530 & 1963 & 3392 & 5355 & 1175 \\
\hline $\operatorname{LSD}_{(0.05)}$ & 452 & & & & & \\
\hline
\end{tabular}

${ }^{2}$ Gross return was calculated as average price of $\$ 7.7 /$ box multiply by average boxes $/ \mathrm{ha}$.

yTotal production cost includes all cost for growing cover crop excluding cost of harvesting cantaloupe.

${ }^{x}$ Harvest was adjusted based on number of boxes harvested per treatment multiply by $\$ 4$ picking cost.

"Total variable cost include production and harvest cost.

"Net return was calculated as gross return minus total variable cost. 


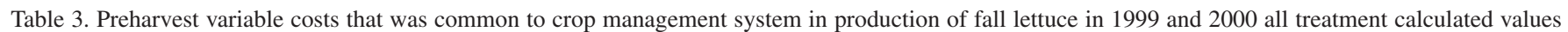
in $(\$ / h a)$.

\begin{tabular}{|c|c|c|c|c|c|c|c|c|c|c|c|c|}
\hline \multirow[b]{2}{*}{ Operation } & \multicolumn{3}{|c|}{ Cowpea mulch } & \multicolumn{3}{|c|}{ Cowpea incorporated } & \multicolumn{3}{|c|}{ Sudangrass } & \multicolumn{3}{|c|}{ Bare ground } \\
\hline & $\mathrm{CON}^{\mathrm{z}}$ & $\mathrm{ICM}^{\mathrm{y}}$ & $\mathrm{ORG}^{\mathrm{x}}$ & $\mathrm{CON}$ & ICM & ORG & $\mathrm{CON}$ & ICM & ORG & $\mathrm{CON}$ & ICM & ORG \\
\hline \multicolumn{13}{|l|}{ Production cost } \\
\hline Stubble disc & --- & --- & --- & 20 & 20 & 20 & 20 & 20 & 20 & --- & --- & --- \\
\hline Subsoil & --- & --- & --- & 35 & 35 & 35 & 35 & 35 & 35 & 35 & 35 & 35 \\
\hline $\operatorname{Disc} 2 x$ & --- & --- & --- & 22 & 22 & 22 & 22 & 22 & 22 & 22 & 22 & 22 \\
\hline Landplane $2 \times$ & --- & --- & --- & 23 & 23 & 23 & 23 & 23 & 23 & 23 & 23 & 23 \\
\hline $\begin{array}{l}\text { Border, cross check } \\
\text { and break }\end{array}$ & 16 & 16 & 16 & 16 & 16 & 16 & 16 & 16 & 16 & 16 & 16 & 16 \\
\hline Wil-Rich Chisel plow & -- & -- & -- & 15 & 15 & 15 & 15 & 15 & 15 & 15 & 15 & 15 \\
\hline Disc $1 \times$ & --- & --- & --- & 11 & 11 & 11 & 11 & 11 & 11 & 11 & 11 & 11 \\
\hline Triplane $1 \times$ & --- & --- & --- & 11 & 11 & 11 & 11 & 11 & 11 & 11 & 11 & 11 \\
\hline \multicolumn{13}{|l|}{$\begin{array}{r}\text { Fertilizer and chicken } \\
\text { manure plus cost of }\end{array}$} \\
\hline List & --- & --- & --- & 14 & 14 & 14 & 14 & 14 & 14 & 14 & 14 & 14 \\
\hline Power mulch beds & --- & --- & --- & 30 & 30 & 30 & 30 & 30 & 30 & 30 & 30 & 30 \\
\hline \multicolumn{13}{|l|}{ Transplant (materials } \\
\hline $\begin{array}{l}\$ 616 \text { plus } 52 \text { h labol } \\
@ \$ 6)\end{array}$ & \multicolumn{7}{|c|}{$\$ 616$ plus $52 \mathrm{~h}$ labor } & 928 & 928 & 928 & 928 & 928 \\
\hline \multicolumn{13}{|c|}{$\begin{array}{l}\text { Install drip and repair } \\
\quad \text { (system } \$ 500 \text { plus }\end{array}$} \\
\hline 10h labor @ \$60) & 560 & 560 & 560 & 560 & 560 & 560 & 560 & 560 & 560 & 560 & 560 & 560 \\
\hline Spike $2 \times$ & 5 & 5 & 5 & 5 & 5 & 5 & 5 & 5 & 5 & 5 & 5 & 5 \\
\hline Hand weed $1 \times$ & 105 & 105 & 105 & 105 & 105 & 105 & 105 & 105 & 105 & 105 & 105 & 105 \\
\hline Irrigation $6 x$ & 100 & 100 & 100 & 100 & 100 & 100 & 100 & 100 & 100 & 100 & 100 & 100 \\
\hline \multicolumn{13}{|l|}{$\begin{array}{l}\text { Insect control } 9 \times \\
\text { (varies within }\end{array}$} \\
\hline Stubble disc & 0 & 0 & 0 & 20 & 20 & 20 & 20 & 20 & 20 & 20 & 20 & 20 \\
\hline Subtotal & 1924 & 1856 & 1860 & 2124 & 2056 & 2059 & 2124 & 2056 & 2059 & 2104 & 2036 & 2039 \\
\hline Land rent & 225 & 225 & 225 & 225 & 225 & 225 & 225 & 225 & 225 & 225 & 225 & 225 \\
\hline \multicolumn{13}{|l|}{$\begin{array}{c}\text { Cash overhead (17\% } \\
\text { subtotal cost and }\end{array}$} \\
\hline Total production cost & 2515 & 2435 & 2439 & 2748 & 2668 & 2673 & 2748 & 2668 & 2673 & 2725 & 2645 & 2649 \\
\hline
\end{tabular}

${ }^{\mathrm{z}} \mathrm{CON}=$ conventional practice.

${ }^{\mathrm{y}} \mathrm{ICM}=$ integrated crop management practice.

${ }^{\mathrm{x}} \mathrm{ORG}=$ organic practice.

for organic cantaloupe varied from $\$ 476 /$ ha to $\$ 2,561 /$ ha compared to a net return from $\$ 723 /$ ha to $\$ 5,627 /$ ha for the integrated management system and $\$ 752 /$ ha to $\$ 5,534 /$ ha for the conventional system. The highest net return was obtained when cantaloupe was grown using the integrated management system after a cowpea-incorporated cover crop. Net returns were \$5,627/ha and \$3,134/ha in 1999 and 2000 , respectively. Cantaloupe production resulted in positive net return for all possible combinations of the four cover crop systems and three crop management practices.

Sensitivity analysis with organic price premium. Sensitivity analysis examined the effect of a $20 \%$ price premium increase in net returns for organic grown lettuce and cantaloupe in 1999 and 2000. In 1999, the net return from organically grown lettuce under cowpea mulch increased to $\$ 1,730 /$ ha, compared to a net return of $\$ 506$ using conventional pricing (Table 4). The net return from organic lettuce under the cowpea-incorporated treatment was even higher at $\$ 2,516 /$ ha. The net return in 2000 lettuce was much higher with the $20 \%$ organic price premium; organic lettuce under to cowpea mulch returned $\$ 4,243 /$ ha. The highest return due to $20 \%$ price premium was in organic lettuce grown under cowpea-incorporated treatments with $\$ 5,971 /$ ha compared to $\$ 3,434$ previously realized using conventional pricing. Using $20 \%$ price premium, the organic lettuce following either sudangrass or bare-ground returned $\$ 2,510$ and $\$ 2,566$ respectively.

Net return in organic cantaloupe was also high with $20 \%$ price premium over conventional pricing in 1999. The organic cantaloupe grown under cowpea mulch gained $\$ 1,899 /$ ha more than previous net return of $\$ 790 /$ ha that used conventional pricing (Table 6). All other organic cantaloupe grown under three other cropping systems returned over $\$ 3,500 /$ ha in 1999. In 2000, organically grown cantaloupe was also profitable due to $20 \%$ price premium with $\$ 1,454 /$ ha for organic cantaloupe under cowpea mulch, $\$ 2,975 /$ ha under cowpea incorporated, \$3,148/ha under sudangrass and $\$ 2,383 /$ ha for organic cantaloupe grown on bare ground. These results suggest that organic lettuce and cantaloupe production would be profitable with a premium price for these crops.

This study indicates that cover crop and crop management practices affect lettuce and cantaloupe yield, as well as the associated net return. The system where summer cowpea cover crop is incorporated into the soil prior to lettuce planting in the fall followed by cantaloupe planting in the spring produced the greatest yield and net return. Results from bare ground, sudangrass, and cowpea mulch systems varied with years. Yield in the organic lettuce system increased with time, with the greatest yield (1,586 boxes/ha) and net return $(\$ 3,434 / \mathrm{ha})$ obtained in the cowpea-incorporated plots. For cantaloupe, the greatest returns $(\$ 5,627 / \mathrm{ha}$ in 1999 and \$3,134/ha in 2000) were obtained in cowpea-incorporated plots, grown using integrated management practices. Organic lettuce production following a cowpea incorporated cover crop showed high potential, with a net return of $\$ 3,434$ without a price premium in 2000. Using the $20 \%$ price premium for organic produce, this system was even more beneficial with a net return of $\$ 5,971$.

Economic return in production of lettuce and cantaloupe in the desert area of Coachella Valley was affected by prior cover crops and in-season management system. In either case, including a summer cowpea into their production techniques could increase their economic return for both organic and conventional vegetable growers.

\section{Literature Cited}

Batte, M.T., D.L. Forster, and F.J. Hitzhusen. 1993. Organic agriculture in Ohio: An economic perspective. J. Prod. Agr. 6:536-542.

Bell, C.E., B.E. Boutwell, E.J. Ogbuchiekwe, and M.E. McGiffen. 2000. Weed control in carrot (Daucus carota L.): The efficacy and economic value of Linuron weed sciences. HortScience 35:1089-1091.

Bond, W., H.C. Moore, R.J. Atkinson, J.R. Bevan, and M.E.K Lennartsson. 1998. Changes in the weed seedbank following different weeding treatments in drilled salad onion and carrot crops 
Table 4. Net returns from crop management system in production of fall lettuce in 1999 and 2000 based upon a partial budget analysis of all treatment calculated values in $(\$ / h a)$.

\begin{tabular}{|c|c|c|c|c|c|c|c|c|}
\hline $\begin{array}{l}\text { Summer } \\
\text { cover crop } \\
\text { system }\end{array}$ & $\begin{array}{l}\text { Crop } \\
\text { management } \\
\text { practice }\end{array}$ & $\begin{array}{c}\text { Avg } \\
\text { yield } \\
\text { (boxes) }\end{array}$ & $\begin{array}{l}\text { Gross } \\
\text { return }\end{array}$ & $\begin{array}{c}\text { Total } \\
\text { production } \\
\text { cost }^{y}\end{array}$ & $\begin{array}{c}\text { Harvest } \\
\operatorname{cost}^{\mathrm{x}}\end{array}$ & $\begin{array}{c}\text { Total } \\
\text { variable } \\
\text { cost }^{\mathrm{w}}\end{array}$ & $\begin{array}{c}\text { Net } \\
\text { return }\end{array}$ & $\begin{array}{c}\text { Net } \\
\text { return }\end{array}$ \\
\hline \multicolumn{9}{|l|}{1999} \\
\hline Cowpea mulch & Conventional & 1001 & 8008 & 2515 & 4154 & 6669 & 1339 & 1339 \\
\hline Cowpea mulch & $\mathrm{ICM}^{\mathrm{r}}$ & 1076 & 8608 & 2435 & 4465 & 6900 & 1708 & 1708 \\
\hline Cowpea mulch & Organic & 765 & 6120 & 2439 & 3175 & 5614 & 506 & 1730 \\
\hline Cowpea incorporated & Conventional & 1406 & 11248 & 2748 & 5835 & 8583 & 2665 & 2665 \\
\hline Cowpea incorporated & ICM & 1320 & 10560 & 2668 & 5478 & 8146 & 2414 & 2414 \\
\hline Cowpea incorporated & Organic & 952 & 7616 & 2673 & 3951 & 6623 & 993 & 2516 \\
\hline Sudangrass & Conventional & 795 & 6360 & 2748 & 3299 & 6047 & 313 & 313 \\
\hline Sudangrass & ICM & 592 & 4736 & 2668 & 2457 & 5125 & -389 & -389 \\
\hline Sudangrass & Organic & 179 & 1432 & 2673 & 743 & 3415 & -1983 & -1697 \\
\hline Bareground & Conventional & 1327 & 10616 & 2725 & 5507 & 8232 & 2384 & 2384 \\
\hline Bareground & ICM & 1127 & 9016 & 2645 & 4677 & 7322 & 1694 & 1694 \\
\hline Bareground & Organic & 516 & 4128 & 2649 & 2141 & 4791 & -663 & 163 \\
\hline $\operatorname{LSD}_{(0.05)}$ & & 296 & --- & --- & --- & --- & --- & --- \\
\hline \multicolumn{9}{|l|}{2000} \\
\hline Cowpea mulch & Conventional & 1028 & 8224 & 2515 & 4466 & 6781 & 1443 & 1443 \\
\hline Cowpea mulch & ICM & 1159 & 9272 & 2435 & 4810 & 7245 & 2027 & 2027 \\
\hline Cowpea mulch & Organic & 1226 & 9808 & 2439 & 5088 & 7527 & 2281 & 4243 \\
\hline Cowpea incorporated & Conventional & 1427 & 11416 & 2748 & 5922 & 8670 & 2746 & 2746 \\
\hline Cowpea incorporated & ICM & 1387 & 11096 & 2668 & 5756 & 8425 & 2671 & 2671 \\
\hline Cowpea incorporated & Organic & 1586 & 12688 & 2673 & 6582 & 9254 & 3434 & 5971 \\
\hline Sudangrass & Conventional & 1196 & 9568 & 2748 & 4963 & 7711 & 1857 & 1857 \\
\hline Sudangrass & ICM & 1265 & 10120 & 2668 & 5250 & 7918 & 2202 & 2202 \\
\hline Sudangrass & Organic & 951 & 7608 & 2673 & 3947 & 6619 & 989 & 2510 \\
\hline Bareground & Conventional & 714 & 5712 & 2725 & 2963 & 5688 & 24 & 24 \\
\hline Bareground & ICM & 769 & 6152 & 2645 & 3191 & 5836 & 316 & 316 \\
\hline Bareground & Organic & 957 & 7656 & 2649 & 3972 & 6621 & 1035 & 2566 \\
\hline $\operatorname{LSD}_{(0.05)}$ & & 275 & --- & --- & --- & --- & --- & --- \\
\hline
\end{tabular}

${ }^{\mathrm{z}}$ Gross return was calculated as average price of $\$ 8 /$ box multiply by average boxes $/$ ha.

yTotal production cost include all costs excluding harvest cost.

${ }^{x}$ Harvest was adjusted based on number of boxes harvested per treatment multiply by $\$ 4.15$ picking cost.

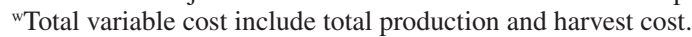

vNet return was calculated as gross return minus total variable cost.

"Net returns calculated using $20 \%$ organic premium price.

${ }^{\mathrm{r}} \mathrm{ICM}=$ integrated crop management practice.

Table 5. Preharvest variable costs that was common to crop management system in production of spring cantaloupe in 1999 and 2000 all treatment calculated values in $(\$ / h a)$.

\begin{tabular}{|c|c|c|c|c|c|c|c|c|c|c|c|c|}
\hline \multirow[b]{2}{*}{ Operation } & \multicolumn{3}{|c|}{ Cowpea mulch } & \multicolumn{3}{|c|}{ Cowpea incorporated } & \multicolumn{3}{|c|}{ Sudangrass } & \multicolumn{3}{|c|}{ Bare ground } \\
\hline & $\mathrm{CON}^{2}$ & $\mathrm{ICM}^{\mathrm{y}}$ & $\mathrm{ORG}^{\mathrm{x}}$ & $\mathrm{CON}$ & ICM & ORG & $\mathrm{CON}$ & ICM & $\overline{\mathrm{ORG}}$ & $\mathrm{CON}$ & ICM & ORG \\
\hline \multicolumn{13}{|l|}{ Production cost } \\
\hline Stubble disc $1 \times$ & 0 & 0 & 0 & 22 & 22 & 22 & 22 & 22 & 22 & 22 & 22 & 22 \\
\hline $\operatorname{Disc} 2 x$ & 0 & 0 & 0 & 23 & 23 & 23 & 23 & 23 & 23 & 23 & 23 & 23 \\
\hline \multicolumn{13}{|l|}{$\begin{array}{l}\text { Spray fertilizer and } \\
\text { chicken manure } 1 \times\end{array}$} \\
\hline @ $\$ 22.50 / 27 \mathrm{cu} \mathrm{ft}$ & 76 & 76 & 45 & 76 & 76 & 45 & 76 & 76 & 45 & 76 & 76 & 45 \\
\hline List and rerun beds & 0 & 0 & 0 & 14 & 14 & 14 & 14 & 14 & 14 & 14 & 14 & 14 \\
\hline \multicolumn{13}{|l|}{ Transplant (materials } \\
\hline @\$6) & 464 & 464 & 464 & 464 & 464 & 464 & 464 & 464 & 464 & 464 & 464 & 464 \\
\hline \multicolumn{13}{|l|}{$\begin{array}{l}\text { Install drip and repair } \\
\text { (system } \$ 500 \text { plus }\end{array}$} \\
\hline 10 h labor @ \$60) & 560 & 560 & 560 & 560 & 560 & 560 & 560 & 560 & 560 & 560 & 560 & 560 \\
\hline \multicolumn{13}{|c|}{ Hand weed $1 \times$, but $2 \times$} \\
\hline for cowpea mulch & 210 & 210 & 210 & 105 & 105 & 105 & 105 & 105 & 105 & 105 & 105 & 105 \\
\hline \multicolumn{13}{|c|}{ Pollination 1.5 hives } \\
\hline @ \$25/hive & 38 & 38 & 38 & 38 & 38 & 38 & 38 & 38 & 38 & 38 & 38 & 38 \\
\hline Irrigation $5 \times$ & 117 & 117 & 117 & 117 & 117 & 117 & 117 & 117 & 117 & 117 & 117 & 117 \\
\hline $\begin{array}{l}\text { Insect control } 2 \times, \\
\text { except organic }\end{array}$ & 30 & 0 & 0 & 30 & 0 & 0 & 30 & 0 & 0 & 30 & 0 & 0 \\
\hline Disc out beds & 0 & 0 & 0 & 22 & 22 & 22 & 22 & 22 & 22 & 22 & 22 & 22 \\
\hline Subtotal & 1494 & 1464 & 1433 & 1469 & 1439 & 1408 & 1469 & 1439 & 1408 & 1469 & 1439 & 1408 \\
\hline Land rent (net hectare & e) 225 & 225 & 225 & 225 & 225 & 225 & 225 & 225 & 225 & 225 & 225 & 225 \\
\hline $\begin{array}{l}\text { Cash overhead ( } 13 \% \\
\text { of subtotal cost and } \\
\text { land rent) }\end{array}$ & 223 & 220 & 216 & 220 & 216 & 212 & 220 & 216 & 212 & 220 & 216 & 212 \\
\hline Total production cost & 1942 & 1908 & 1874 & 1914 & 1880 & 1845 & 1914 & 1880 & 1845 & 1914 & 1880 & 1845 \\
\hline
\end{tabular}

${ }^{\mathrm{z}} \mathrm{CON}=$ conventional practice.

y ICM = integrated crop management practice.

${ }^{\mathrm{x}} \mathrm{ORG}=$ organic practice. 
Table 6. Net returns from crop management system in production of spring cantaloupe in 1999 and 2000 based on a partial budget analysis of all treatment calculated values in $(\$ / \mathrm{ha})$.

\begin{tabular}{|c|c|c|c|c|c|c|c|c|}
\hline $\begin{array}{l}\text { Summer } \\
\text { cover crop } \\
\text { system }\end{array}$ & $\begin{array}{l}\text { Crop } \\
\text { management } \\
\text { practice }\end{array}$ & $\begin{array}{c}\text { Avg } \\
\text { yield } \\
\text { (boxes) }\end{array}$ & $\begin{array}{l}\text { Gross } \\
\text { return }^{z}\end{array}$ & $\begin{array}{c}\text { Total } \\
\text { production } \\
\text { cost }^{\mathrm{y}}\end{array}$ & $\begin{array}{c}\text { Harvest } \\
\operatorname{cost}^{\mathrm{x}}\end{array}$ & $\begin{array}{c}\text { Total } \\
\text { variable } \\
\text { cost }^{\mathrm{w}}\end{array}$ & $\begin{array}{c}\text { Net } \\
\text { return }^{v}\end{array}$ & $\begin{array}{c}\text { Net } \\
\text { return }\end{array}$ \\
\hline \multicolumn{9}{|l|}{1999} \\
\hline Cowpea mulch & Conventional & 954 & 7346 & 1942 & 3816 & 5758 & 1588 & 1588 \\
\hline Cowpea mulch & $\mathrm{ICM}^{\mathrm{t}}$ & 860 & 6622 & 1908 & 3440 & 5348 & 1274 & 1274 \\
\hline Cowpea mulch & Organic & 720 & 5544 & 1874 & 2880 & 4754 & 790 & 1899 \\
\hline Cowpea incorporated & Conventional & 2013 & 15500 & 1914 & 8052 & 9966 & 5534 & 5534 \\
\hline Cowpea incorporated & ICM & 2029 & 15623 & 1880 & 8116 & 9996 & 5627 & 5627 \\
\hline Cowpea incorporated & Organic & 1099 & 8462 & 1845 & 4396 & 6241 & 2221 & 3913 \\
\hline Sudangrass & Conventional & 1562 & 12027 & 1914 & 6248 & 8162 & 3866 & 3866 \\
\hline Sudangrass & $\mathrm{ICM}$ & 1615 & 12436 & 1880 & 6460 & 8340 & 4096 & 4096 \\
\hline Sudangrass & Organic & 1105 & 8509 & 1845 & 4420 & 6265 & 2243 & 3945 \\
\hline Bareground & Conventional & 1215 & 9356 & 1914 & 4860 & 6774 & 2582 & 2582 \\
\hline Bareground & ICM & 1345 & 10357 & 1880 & 5380 & 7260 & 3097 & 3097 \\
\hline Bareground & Organic & 1191 & 9171 & 1845 & 4764 & 6609 & 2561 & 4395 \\
\hline $\operatorname{LSD}_{(0.05)}$ & & 782 & --- & --- & --- & --- & --- & --- \\
\hline \multicolumn{9}{|l|}{2000} \\
\hline Cowpea mulch & Conventional & 728 & 5606 & 1942 & 2912 & 4854 & 752 & 752 \\
\hline Cowpea mulch & ICM & 711 & 5475 & 1908 & 2844 & 4752 & 723 & 723 \\
\hline Cowpea mulch & Organic & 635 & 4890 & 1874 & 2540 & 4414 & 476 & 1454 \\
\hline Cowpea incorporated & Conventional & 1284 & 9887 & 1914 & 5136 & 7050 & 2837 & 2837 \\
\hline Cowpea incorporated & ICM & 1355 & 10434 & 1880 & 5420 & 7300 & 3134 & 3134 \\
\hline Cowpea incorporated & Organic & 920 & 7084 & 1845 & 3680 & 5525 & 1559 & 2975 \\
\hline Sudangrass & Conventional & 1348 & 10380 & 1914 & 5392 & 7306 & 3074 & 3074 \\
\hline Sudangrass & ICM & 1035 & 7970 & 1880 & 4140 & 6020 & 1950 & 1950 \\
\hline Sudangrass & Organic & 953 & 7338 & 1845 & 3812 & 5657 & 1681 & 3148 \\
\hline Bareground & Conventional & 1099 & 8462 & 1914 & 4396 & 6310 & 2153 & 2153 \\
\hline Bareground & ICM & 937 & 7215 & 1880 & 3748 & 5628 & 1587 & 1587 \\
\hline Bareground & Organic & 807 & 6214 & 1845 & 3228 & 5073 & 1140 & 2383 \\
\hline $\operatorname{LSD}_{(0.05)}$ & & 652 & --- & --- & --- & --- & --- & --- \\
\hline
\end{tabular}

${ }^{2}$ Gross return was calculated as average price of $\$ 7.7 /$ box multiply by average boxes /ha.

yTotal production cost include all costs excluding harvest cost.

${ }^{x}$ Harvest was adjusted based on number of boxes harvested per treatment multiply by $\$ 4.0$ picking cost.

wTotal variable cost include total production and harvest costs.

${ }^{v}$ Net return was calculated as gross return minus total variable cost.

"Net returns calculated using $20 \%$ organic premium price.

${ }^{\mathrm{r}} \mathrm{ICM}=$ integrated crop management practice.

grown in organic and conventional systems. Biol. Agr. Hort. 16:203-215.

Brumfield, R.G., A. Rimal, and S. Reiners. 2000. A comparative cost analysis of conventional, integrated crop management, and organic methods. HortTechnology 10(4):165-173.

Buys, J. 1993. Conversion towards organic agriculture in Russia: A preliminary study. Biol. Agr. Hort. 10:125-140.

Centro Internacional de Mejoramiento de Maiz y Trigo, Manual. 1988a. From agronomic data to farmer recommendation: An economic training manual. (rev. ed.) Mexico, D.F.

Centro Internacional de Mejoramiento de Maiz y Trigo, Manual. 1988b. From agronomic data to farmer recommendation: An economic training manual. (rev. ed.) Mexico, D.F.

Clark, M.S., W.R. Horwath, C. Shennan, K.M. Scow, W.T. Lanini, and F. Howard. 1999.
Nitrogen, weeds and water as yield limiting factors in conventional, low-input, and organic tomato systems. Agr. Ecosystems Environ. 73:257-270.

Liebman, M. and A.S. Davis. 2000. Integration of soil, crop and weed management in low-externalinput farming systems. Weed Res. 40:27-47.

Creamer N.G. and K.R. Baldwin. 2000. An evaluation of summer cover crops for use in vegetable production systems in North Carolina. HortScience 35:600-603.

Mayberry, K.M., R.A. Natwick, A. Gonzalez, G.H. Holmes, C.E. Bell, and K.M. Bali. 1995. Guidelines to production costs and practices. Circular 104-V. Univ. of Calif. Coop. Ext., Imperial Co.

McGiffen, Jr., M.E., J.D. Ehlers, and J.L. Aguiar. 2000. Introduction to organic horticulture colloquium. HortTech. 10:661-662.
Ngouajio, M. and M.E McGiffen Jr. 2001. Cropping systems for intensive desert vegetable production. < http://cnas.ucr.edu/ bps/hcoopextcrop. html.>

Ngouajio M. and M.E. McGiffen Jr. 2002. Going organic changes weed population dynamics. HortTechnology 12:590-596.

Ngouajio M., M.E. McGiffen Jr., and C.M. Hutchinson. 2003 Effect of cover crop and management system on weed populations in lettuce. Crop Protection 22:57-64.

Ogbuchiekwe, E.J. and M.E McGiffen Jr. 2001. Efficacy and Economic Value of Weed Control for Drip and Sprinkler Irrigated Celery. HortScience 36:1278-1282.

U.S. Department of Agriculture Marketing Services. 2001.http:/www.ams.usda.gov/mncs/mnreport/ WA_FV120.txt>. 